\title{
Complementary feeding implementation in Pintu Padang Health Centre, South Tapanuli District, Indonesia: a qualitative study
}

\author{
*Cecep Triwibowo ${ }^{1}$, Rusdi Rangkuti ${ }^{2}$, Ridesman ${ }^{2}$, Niniek Lely Pratiwi ${ }^{3}$, Tinah ${ }^{1}$, Lita Heni \\ Kusumawardani ${ }^{4}$, Yulia Fauziyah ${ }^{5}$
}

Sri Lanka Journal of Child Health, 2021; 50(1): 63-68

\begin{abstract}
Introduction: Nutritional status is very closely related to the complementary feeding $(\mathrm{CF})$ given to infants. Inappropriate $\mathrm{CF}$ practice is still commonly found in Indonesia.
\end{abstract}

Objectives: To examine the practice of $\mathrm{CF}$ in the area of Pintu Padang Health Centre in South Tapanuli District, Indonesia.

Method: This is a qualitative study with a focus group discussion (FGD) approach. Purposive sampling was used to collect 20 respondents from amongst community leaders, district level health officers (nutritionists), health centre officers, midwives and Posyandu (integrated service post) cadres. The FGD was guided by a moderator and recorded using a tape recorder. The results of the FGD recording were transformed by verbatim analysis and turned into sub themes and themes.

Results: Two themes were defined after analysing the information on $\mathrm{CF}$ implementation, which are early $\mathrm{CF}$ and inadequate nutritional intake. Early CF was based on four sub themes, namely 'prelacteal feeding', 'not understanding the readiness of children to be fed by CF', 'lack of support system' and 'lack of knowledge'. Inadequate nutritional intake occurred because CF implementation was not provided to babies based on the principle of balanced nutrition and was processed improperly.

\section{${ }^{1}$ Health Polytechnic of Medan, Indonesia, ${ }^{2}$ Provincial Health Office of North Sumatera, Indonesia, ${ }^{3}$ National Institute of Health Research and Development, Ministry of Health Republic of Indonesia, ${ }^{4}$ Faculty of Health and Sciences, Jenderal Soedirman University, Purwokerto, Indonesia, ${ }^{5}$ Faculty of Medicine, Jenderal Soedirman University, Purwokerto, Indonesia *Correspondence: elfatih05@gmail.com}

https://orcid.org/0000-0001-8068-8076

(Received on 28 February 2020: Accepted after revision on 24 April 2020)

The authors declare that there are no conflicts of interest

Personal funding was used for the project.

Open Access Article published under the Creative

Commons Attribution CC-BY (C) (i) License
Conclusions: Practice of $\mathrm{CF}$ in the area of Pintu Padang Health Centre in South Tapanuli is still inappropriate considering what WHO recommends.

DOI: http://dx.doi.org/10.4038/sljch.v50i1.9403

(Key words: Early complementary feeding, inadequate nutritional intake, under two children)

\section{Background}

Stunting is defined as the impaired growth and development of children under five, usually due to poor nutrition, especially within the first 1,000 days of life or because of repeated infection ${ }^{1}$. Stunting is now identified as a global health priority. A target to reduce the number of stunted children under-five in Indonesia is by $40 \%$ between 2010 and $2025^{2}$. The prevalence of stunting in Indonesia is higher than in other South Asian countries, such as Myanmar (35\%), Vietnam (23\%), Malaysia (17\%), Thailand $(16 \%)$ and Singapore $(4 \%)^{3}$. A target to reduce the number of stunted children under-five in Indonesia was by $28 \%$ between 2015 and $2019^{4}$. Data from Riset Kesehatan Dasar (RISKESDAS) research conducted by Ministry of Health, Republic of Indonesia (2018) reported that the prevalence of malnutrition was $17.7 \%$ and the prevalence of stunting of children aged under-two was $29.9 \%{ }^{5}$. Nutritional status is closely related to the pattern of complementary feeding (CF) implementation based on the WHO recommendation, which is to start at six months of age.

Children are defined as stunted if their height-forage is less than the applicable national standard in the Kesehatan Ibudan Anak (KIA) book (a book of mother and infant health record) and other national documents $^{7}$. It is crucial to reduce the stunting prevalence as early as possible to hinder the adverse long term effects on children such as impaired growth and development. Inappropriate CF practice, in quality and quantity, is identified as a key factor causing malnutrition and stunting. Early CF practice causes several health problems such as diarrhoea and infection, whereas too late CF implementation causes inadequate nutrition ${ }^{8}$. CF practice at the age of 6-12 months in Indonesia does not meet the standard stipulated by WHO resulting in a low energy intake and deficiency in micronutrients 9 . 
Energy, protein, and vitamin $\mathrm{A}$ and $\mathrm{C}$ intake for children age 0.5-12 years old are less than the Angka Kecukupan Gizi (AKG) (the Indonesian dietary recommendation), which is recommended by the Ministry of Health, Republic of Indonesia ${ }^{10}$. Low micronutrient and macronutrient intake can lead children to suffer from malnutrition. The three major problems of CF practice are 1) poor quality food (low in micronutrients, unvaried food, food that is low in animal protein and low in energy carbohydrates), 2) inadequate CF practice (lack of feeding frequency particularly while babies are ill or recovering from sickness, and inadequate food quantity), 3) the hygienic preparation and storage of food and drinks (contaminated food and drinks, unsafe food preparation and storage $)^{11,12}$. Based on the above facts, it is important to carry out a study to explore more about the practice of $\mathrm{CF}$ in Indonesian society.

\section{Objectives}

The aim of this study was to examine mothers' CF practice based on the perspective of professional health workers, Posyandu (integrated service post) cadres and community leaders.

\section{Method}

Study setting: This qualitative study with focus group discussion (FGD) approach was conducted in Pintu Padang Health Centre, South Tapanuli District, North Sumatera Province, Indonesia.
Participants and recruitment: The purposive sampling technique was applied in order to collect 20 respondents who consisted of community leaders, district level health officers (nutritionists), health centre officers, midwives and Posyandu cadres.

Data retrieval: The FGD was guided by a moderator and recorded using a tape recorder. The materials of the FGD included complementary feeding implementation in local society, common obstacles and any support system regarding the CF implementation.

Data analysis: The results of the FGD recording were transformed by verbatim analysis and turned into sub themes and themes. Participants' identity was coded by P1, P2, P3, etc. to maintain confidentiality.

Ethical issues: Ethical clearance was obtained from the Ethics Committee of the Health Research and Development Agency of Ministry of Health Republic of Indonesia (ERC No. LB.02.01/2/ KE.227/2019). Written informed consent was taken from the mothers participating in study.

\section{Results}

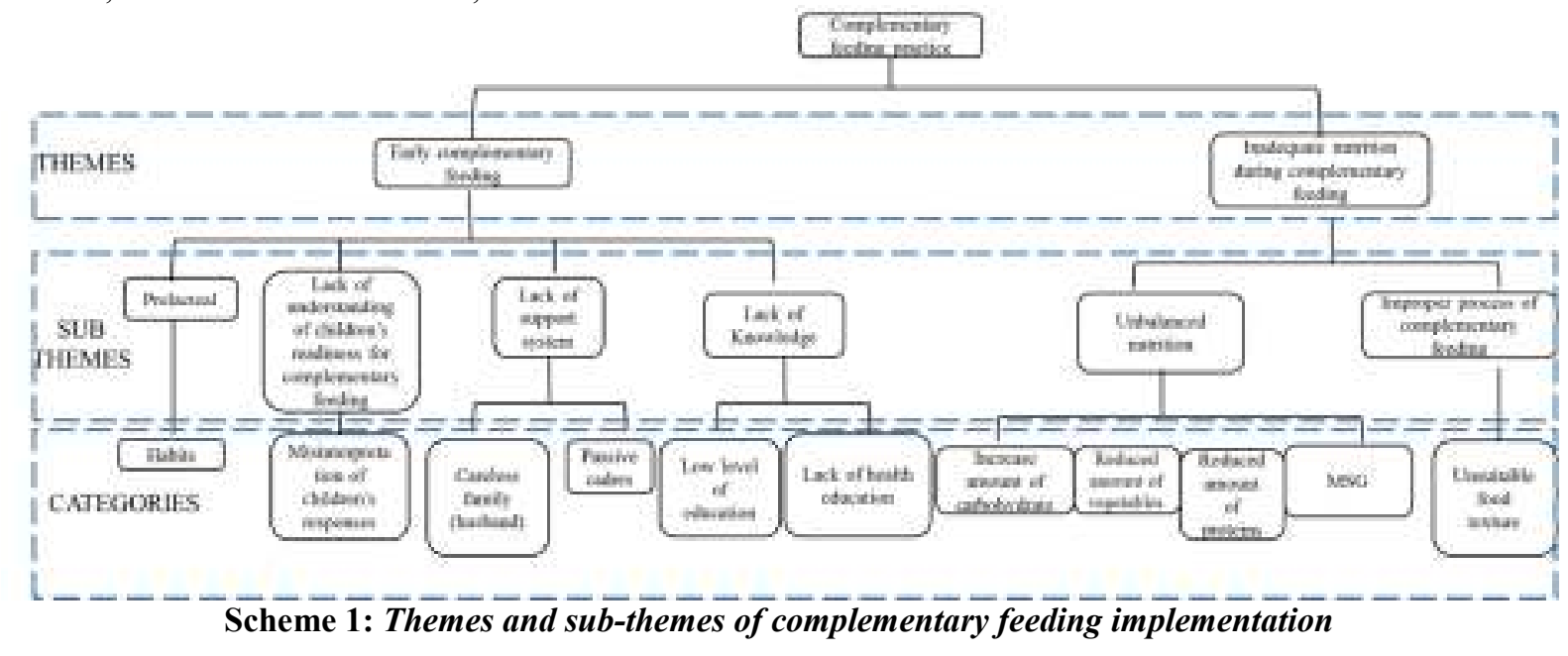

Two themes were defined after analysing the information on $\mathrm{CF}$ implementation, which were early $C F$ and inadequate nutritional intake. The first theme, early $C F$, emerged based on four sub themes found.

'Pre-lacteal feeding' is the first sub theme that was discovered based on key words such as 'honey provided to a newborn' (as depicted in the discussion below):

"Those who are not exclusively breastfed are usually given honey or formula milk"
"Exclusive breastfeeding is not easy; newborns are provided with sugar water or honey"

"Newborns are given pure water"

"Regarding this sugar water, I don't know any more even though midwives have already informed it. Because it is usual."

"This is what we were informed, it is too early to introduce food"

The second sub theme is 'not understanding the readiness of children to be fed by $C F$ '. Parents misinterpreted children's responses: infant cries are 
commonly considered as due to them being in a hungry condition and therefore need to be given meals. The interview excerpts are as follows:

"If babies cry, parents give it (food) to them. They believe that their babies will be calm with food without considering the harmful effect of early CF."

"Sometimes, the most important thing is their babies are quiet."

The next sub theme is 'lack of support system' from family, particularly careless husbands, and health cadres as an external factor who passively support mothers. Excerpts of the interview are as follows:

"That is mum's business"

"I only asked 'Has the baby had a shower? Has the baby been fed?' (laughing) I didn't ask further such as what kinds of food..."

"So, if community midwives do not get actively involved, no one supports mothers."

"Health cadres generally came late to activities (meeting). We used to call them by a mosque loudspeaker but they still did not join in the activities"

The last sub theme that emerges regarding early $\mathrm{CF}$ is 'lack of knowledge' because of the low level of education (the majority of people's educational level is secondary school) and lack of health education by cadres.

"Cadres did not explain the correct process to prepare CF"

"The majority of mothers and families do not understand how to make suitable complementary foods based on children's age"

"The majority of mothers are secondary school graduates)"

"I think it takes effect, generally they graduated from secondary school level"

The second theme that emerged from the $\mathrm{CF}$ implementation issue is inadequate nutritional intake during the $\mathrm{CF}$ period, which is defined as such because CF implementation was not provided to babies based on the principle of balanced nutrition and was processed improperly. The theme is supported by categories such as the dominance of carbohydrates, lack of vegetables, lack of protein and the use of monosodium glutamate (MSG). Interview excerpts are as follows:

"(Six months) rice"

"Lots of MSG"

"SU*, is now commercial, Pro*in*"

"Only the water (of broth)"

"Still, MSG"

"Cooking soup at their home then we gave the broth to babies"
"Using MSG, family meals are for babies as well. The vegetables (in soup) are for parents and the broth is for babies"

"The babies are given mushy rice without vegetables"

The category of an improper $C F$ process is based on unsuitable food texture for age.

"Sometimes we found 2-week old babies were given CF using a bottle. Tajin water (rice washing water) is given when 3-months old; bakwan (salted fried meal consisting of vegetables and batter) at 4months old; crisps at 3-months old; and mushy rice at 6-months old"

\section{Discussion}

Stunting influences brain development, which can lead to a non-optimal level of intelligence ${ }^{13}$ resulting in the risk of reduced productivity in adulthood. Moreover, stunting makes children more vulnerable to diseases and furthermore, they have a higher risk of suffering from chronic diseases in their adult years. Stunting affects the level of intelligence, vulnerability to disease, causes decreased productivity and then inhibited economic growth, increased poverty and inequality ${ }^{14}$. Therefore, efforts to handle and prevent stunting need to be done on a massive scale in order to improve the health status of society. The aetiology of stunting is considered complex but the major cause is a behavioural factor that can actually be prevented and modified ${ }^{13}$. Public health phenomena related to socio-ecological factors, such as stunting, needs an integrated approach to reduce the causative factors and appropriate interventions are needed to solve the problem ${ }^{15}$. One of the interventions to prevent stunting that is considered crucial is correct $\mathrm{CF}$ implementation for children under five.

Two themes resulted from the discussion during the interview process with informants, which were early $C F$ implementation and inadequate nutritional intake. Honey is a common pre-lacteal food that is given to newborns in Pintu Padang due to family beliefs or tradition. The majority of respondents believe that honey can make their babies stronger because this is what their ancestors said. Respondents still practise this family tradition and belief. Crying babies are always interpreted as being either hungry or thirsty. It is due to this that the majority of respondents give pre-lacteal food immediately to babies when they cry. Babies fussing is one of the reasons why they introduce $\mathrm{CF}$. Knowledge is vital for the success or failure of exclusive breastfeeding. Early $\mathrm{CF}$ can result from a lack of knowledge or understanding with regards to correct food for babies ${ }^{16}$. 
A qualitative study stated that following the WHO guideline of providing $\mathrm{CF}$ at the age of six months to babies is challenging to mothers; although the majority of respondents within the study knew about this guideline. Moreover, the misleading belief that $\mathrm{CF}$ can increase the baby's weight makes the recommendation more difficult to obey ${ }^{17}$. Generally, babies are introduced to CF at the age of 4.3 months, whereas the mothers are aware that the recommended age by the WHO is six months old ${ }^{18}$. In qualitative studies ${ }^{19,20}$, there are four reasons, which further become themes, for why mothers give $\mathrm{CF}$ too early, which are 1) the readiness of children to eat varies from one to another, 2) significant others suggest many different advice, 3 ) "the way to pay attention to the babies' intestine is by giving meals" and it's interpreted as being a good mother if one practises that advice, and 4) giving CF too early or too late is not an issue because a guideline is only a recommendation not a prerequisite. Testimonials from peers who have practised early CF becomes a source of strength for mothers who have done the same thing.

Building trust with professional health workers is an important factor when applying the right $\mathrm{CF}$, which is recommended by the WHO. Professional health workers inform or advise with regards to $\mathrm{CF}$ in accordance with the WHO recommendations, which is that the CF is to be given to six month old babies because at that age they are developmentally ready to start $\mathrm{CF}$ and accept it easily and enthusiastically $^{14,21}$. Lack of support from husbands influences the practice of $\mathrm{CF}$ as well. Many husbands consider that food and children are only the mothers' business, whereas raising a child should be teamwork between husband and wife. Being indifferent to the development and growth of children is not a wise attitude.

Nutrient content during the CF period is an important thing to be concerned with in order to maximise infants' growth and development. Within this research, we found that the majority of parents did not provide balanced nutrition in terms of the $\mathrm{CF}$ given to their babies (as WHO recommends), which consists of carbohydrates, vegetable and animal proteins, vitamins, minerals and fats. The majority of respondents confessed that they gave a large amount of carbohydrates with only a little vegetables or animal proteins ${ }^{22}$ with some added MSG, such as crisps. This is contrary to the WHO recommendation to use natural herbs as flavouring for baby food.

\section{Conclusions}

This qualitative study discovered two themes from the complementary feeding implementation in Pintu Padang Health Centre, South Tapanuli
District, which are early CF and inadequate nutritional intake.

\section{Acknowledgments}

We would like to thank the National Institute of Health Research and Development, Ministry of Health Republic of Indonesia for the Risbinkesda grant. Our sincere thanks go to the informants who were willing to be guest speakers in the FGD and government of South Tapanuli District who gave continuous support while this research was conducted.

\section{References}

1. Bappenas KP. Stunting reduction intervention. 2018; (November).

2. Kementerian Kesehatan RI. Indonesian Health Profile 2015. 2016. 403 p.

3. Paciorek CJ, Stevens GA, Finucane MM, Ezzati M, Barquera S, Bhutta Z, et $a l$. Children's height and weight in rural and urban populations in low-income and middle-income countries: A systematic analysis of populationrepresentative data. Lancet Global Health 2013; 1(5):e300-9.

https://doi.org/10.1016/S2214109X(13) 70109-8

4. Kemenkes RI. Ministry of Health Strategic Plan for 2015 - 2019. 2016; 7 April.

5. Badan Penelitian dan Pengembangan Kesehatan. Riset Kesehatan Dasar (RISKESDAS) 2019. Lap Nas 2019. 2019; 1-384.

6. Kementrian RI. Integrated stunting intervention in 2018. 2018; 11-23.

7. Pritasari K. The evaluation of the 2018 implementation and the 2019 action plan. Kementeri Kesehat [Internet]. 2018; (November 2018):1-47. Available from: http://www.depkes.go.id/

8. Nugraheni SD, Prabamurti PN, Riyanti E. Complementary Feeding Implementation as a factor of exclusive breastfeeding failure on primiparous mothers (A case study in Pudakpayung). J Kesehat Masy. 2018; 6(5):804-13. 
9. Dehdari T, Rahimi T, Aryaeian N, Gohari MR. Effect of nutrition education intervention based on Pender's Health Promotion Model in improving the frequency and nutrient intake of breakfast consumption among female Iranian students. Public Health Nutrition 2016; 17(3):657-66.

https://doi.org/10.1017/S136898001300 0049

PMid: 23360695

10. Kemenkes RI. Kesehatan dalam Kerangka Sustainable Development Goals (SDGs). Rakorpop Kementeri Kesehat RI [Internet]. 2015; (97):24. Available from:

http://www.pusat2.litbang.depkes.go.id/ pusat2_v1/wp-

content/uploads/2015/12/SDGs-DitjenBGKIA.pdf

11. Gabida M, Chemhuru M, Tshimanga M, Gombe NT, Takundwa L, Bangure D. Effect of distribution of educational material to mothers on duration and severity of diarrhoea and pneumonia, Midlands Province, Zimbabwe: a cluster randomized controlled trial. International Breastfeeding Journal 2015; 10:13.

https://doi.org/10.1186/s13006-0150037-6

PMid: 26246847 PMCid: PMC4525732

12. Lin W, Bs HY, Ms $\mathrm{CH}$, Pan W. Nutrition knowledge, attitude, and behaviour of Taiwanese elementary school children. Asia Pacific Journal of Clinical Nutrition 2007; 16(Suppl 2):534-46.

13. Tariku A, Biks GA, Derso T, Wassie MM, Abebe SM. Stunting and its determinant factors among children aged 6-59 months in Ethiopia. Italian Journal of Pediatrics 2017; 43(1): 112. https://doi.org/10.1186/s13052-0170433-1

PMid: 29258578 PMCid: PMC5735819

14. Lu C, Mejia-Guevara I, Hill K, Farmer P. Community-based health financing and child stunting in rural Rwanda. American Journal of Public Health 2016; 106(1):e1-e7.

https://doi.org/10.2105/AJPH.2015.302 913

PMid: 26562109 PMCid: PMC4743535
15. Dewey KG, Adu-Afarwuah S. Systematic review of the efficacy and effectiveness of complementary feeding interventions in developing countries. Maternal and Child Nutrition 2008; 4(s1): 24-85.

https://doi.org/10.1111/j.17408709.200 7.00124.X

PMid: 18289157

16. Reinbott A, Schelling A, Kuchenbecker $\mathrm{J}$, Jeremias T, Russell I, Kevanna O, et al. Nutrition education linked to agricultural interventions improved child dietary diversity in rural Cambodia. British Journal of Nutrition 2016; 116(8):1457-68.

https://doi.org/10.1017/S000711451600 3433

PMid: 27702425 PMCid: PMC5082286

17. Sofiatin Y, Pusparani A, Judistiani TD, Rahmalia A; Diana A; Alisjahbana A. Maternal and environmental risk for faltered growth in the first 5 years for Tanjungsari children in West Java, Indonesia. Asia Pacific Journal of Clinical Nutrition 2019; 28(Suppl 1): S32-S42.

18. Bhutta ZA, Das JK, Rizvi A, Gaffey $\mathrm{MF}$, Walker $\mathrm{N}$, Horton $\mathrm{S}$, et al. Evidence-based interventions for improvement of maternal and child nutrition: What can be done and at what cost? Lancet 2013; 382(9890): 452-77. https://doi.org/10.1016/S01406736(13) 60996-4

19. Giao H, Le An P, Vien NT, Khanh TV, Vinh BQ. Stunting and overweight among 12-24-Month-old children receiving vaccination in Ho Chi Minh City, Vietnam. BioMed Research International 2019; 2019: Article ID 1547626.

https://doi.org/10.1155/2019/1547626

PMid: 30911539 PMCid: PMC6399549

20. Derso T, Tariku A, Biks GA, Wassie MM. Stunting, wasting and associated factors among children aged 6-24 months in Dabat health and demographic surveillance system site: A community based cross-sectional study in Ethiopia. BMC Pediatrics 2017; 17: Article No. 96. 
https://doi.org/10.1186/s12887-017-

0848-2

PMid: 28376746 PMCid: PMC5379504

21. Wirth JP, Matji J, Woodruff BA, Chamois S, Getahun Z, White JM, et al. Scale up of nutrition and health programs in Ethiopia and their overlap with reductions in child stunting. Maternal and Child Nutrition 2017; 13: Article ID 12318.

https://doi.org/10.1111/mcn.12318

PMid: 27132587

22. Grace K, Nagle NN, Husak G. Can small-scale agricultural production improve children's health? Examining stunting vulnerability among very young children in Mali, West Africa. Annals of the American Association of Geographers 2016; 106(3): https://doi.org/10.1080/24694452.2015. 1123602

23. Kureishy S, Khan GN, Arrif S, Ashraf $\mathrm{K}$, Cespedes A, Habib MA, et al. A mixed methods study to assess the effectiveness of food-based interventions to prevent stunting among children under- five years in Districts Thatta and Sujawal, Sindh Province, Pakistan: study protocol. BMC Public Health 2017; 17: Article No.24. https://doi.org/10.1186/s12889-0163976-y

PMid: 28056945 PMCid: PMC5216601 